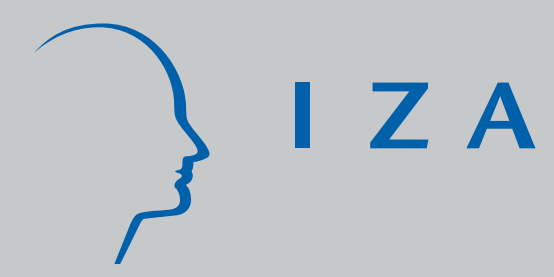

IZA DP No. 1875

Wage and Employment Effects of Immigration to Germany: Evidence from a Skill Group Approach

Holger Bonin

December 2005 


\title{
Wage and Employment Effects of Immigration to Germany: Evidence from a Skill Group Approach
}

\author{
Holger Bonin \\ IZA Bonn
}

Discussion Paper No. 1875

December 2005

\author{
IZA \\ P.O. Box 7240 \\ 53072 Bonn \\ Germany
}

Phone: +49-228-3894-0

Fax: +49-228-3894-180

Email: iza@iza.org

\begin{abstract}
Any opinions expressed here are those of the author(s) and not those of the institute. Research disseminated by IZA may include views on policy, but the institute itself takes no institutional policy positions.

The Institute for the Study of Labor (IZA) in Bonn is a local and virtual international research center and a place of communication between science, politics and business. IZA is an independent nonprofit company supported by Deutsche Post World Net. The center is associated with the University of Bonn and offers a stimulating research environment through its research networks, research support, and visitors and doctoral programs. IZA engages in (i) original and internationally competitive research in all fields of labor economics, (ii) development of policy concepts, and (iii) dissemination of research results and concepts to the interested public.
\end{abstract}

IZA Discussion Papers often represent preliminary work and are circulated to encourage discussion. Citation of such a paper should account for its provisional character. A revised version may be available directly from the author. 
IZA Discussion Paper No. 1875

December 2005

\section{ABSTRACT \\ Wage and Employment Effects of Immigration to Germany: Evidence from a Skill Group Approach}

The paper analyzes the labor market impact of migration by exploiting variation in the labor supply of foreigners across groups of workers with the same level of education but different work experience. Estimates on the basis of German register data for the period 1975-97 do not confirm the hypothesis that penetration of migrants into skill cells has a significant negative effect on the earnings and employment opportunities of native men. The results indicate that a 10 percent rise of the share of immigrants in the workforce would in general reduce wages by less than one percent and not increase unemployment. Though the adverse effects appear stronger for less-qualified and older workers, the evidence altogether sharply contrasts that from a parallel study for the United States indicating a consistent and substantial negative impact of an immigrant labor supply shock on native competitors.

JEL Classification: J15, J31, J42

Keywords: labor market effects of immigration, skill groups, wage elasticity, Germany

Corresponding author:

Holger Bonin

IZA

P.O. Box 7240

53072 Bonn

Germany

Email: bonin@iza.org 


\section{Introduction}

The question how immigration affects the employment opportunities of the native workforce is a long-debated empirical issue in labor economics. In the basic model of a competitive labor market, unless the labor demand curve is perfectly elastic, it is clear that an inflow of immigrant labor should lead to a higher wage or lower unemployment for local workers whose skills are complementary, and have a negative impact on natives whose skills are substitutes. Yet empirically it has been proven very difficult to substantiate the hypothesis that an immigrant influx has an adverse effect on competing native workers. It appears that the conclusion to be drawn from the large number of available studies, see Borjas (1994) and Lalonde and Topel (1996) for surveys, is that immigration does not have a sizeable and significant effect on employment and wages of natives in the same segment of the labor market, even when the immigrant supply shock is large.

If migrants penetrate a closed labor market at random, the correlation between the change in outcomes for natives on this labor market and the change in the share of immigrants in the relevant workforce measures the impact of immigration on competing natives. The typical empirical analysis, beginning with Grossmann (1982), defines the relevant labor market in geographic terms. Perhaps the most influential study on the correlation between natives' wages and the number of immigrants in a locality analyzes the impact of the Mariel boatlift from Cuba to the metropolitan area of Miami- although this exogenous shock raised the local workforce quite dramatically, Card (1990) does not find evidence for a significant adverse effect on natives' employment and wages.

However, the spatial approach may yield biased results. First, immigrants tend to arrive in areas where the potential return to their particular skills is especially high (Borjas 2001). This may lead to a spurious positive correlation between the share of immigrants and the labor market outcomes of locals, which is difficult to control even by use of instruments (Altonji and Card 1991). Second, the effects of a local supply shock from international migration may spread beyond the locality, if capital or native workers respond by relocating. If, for example, native workers respond to a deterioration of local employment opportunities by moving to other labor markets, the measured impact of the immigrant shock will be small

since immigration eventually affects all local labor markets. An empirical approach to handle this problem is to jointly analyze the native migration decisions and labor market 
outcomes (Card 2001), but in any case it remains difficult to control the role of capital movements.

As an alternative to the geographic approach, Borjas (2003) proposes to study the market for skills as an analogy to the closed market consistent with the textbook model of labor supply and demand. The underlying idea is that workers with the same level of education participate in a national labor market, but are imperfect substitutes if they are endowed with different levels of work experience. Under this assumption, there may be sufficient exogenous variation to identify an effect on competing natives, if the immigrant supply shock is not evenly balanced across schooling and experience cells, and over time. The advantage of this strategy is that the size of the native workforce in each skill cell is almost fixed, which means that the potential for reallocation processes contaminating the estimates is reduced.

This study takes the skill group approach to German register data covering the period 1975-97- the Regional File of the IAB Employment Subsample. Our estimates do not support the hypothesis that penetration of migrants into education-experience cells has a significant negative impact on the earnings and employment opportunities of native men. The results indicate that a 10 percent rise of the immigrant share in the workforce at most reduces natives' wages by less than one percent and does not increase unemployment. Though adverse effects appear somewhat stronger for less-qualified and older workers, our evidence for Germany altogether strongly contrasts that by Borjas (2003) who presents very robust empirical evidence indicating that over the past decades, immigration to the United States has substantially worsened the labor market opportunities of native workers in the same skill group as migrants.

The remainder of the paper is structured as follows. The next section elaborates on the empirical strategy to measure the labor market impact of immigration on the basis of skill groups. Section 3 discusses the data, whereas Section 4 presents our estimation results. Section 5 concludes.

\section{Estimating the Impact of Immigration via Skill Groups}

The basic laws of supply and demand have clear-cut implications for how a supply shock should affect prices and quantities in an isolated market. Given an upward-sloping labor 
supply curve, the outcome of an immigrant supply shock, which shifts the supply curve outward, is a decline in wages reducing the amount of labor supplied by the competing incumbent workforce. Hence native unemployment increases. The fundamental prediction of a real wage decline in general also holds in a more elaborated framework where immigration is allowed to affect prices of goods produced and therefore shifts the labor demand curve (Johnson 1980). In principle labor market conditions for competing native workers can only remain constant, if labor demand is insensitive to wages. In this case the market would absorb any additional labor supply from immigrants at the prevailing real wage of natives. However, there is little empirical evidence that the labor demand curve could be perfectly elastic (Hamermesh 1993).

These considerations are valid for any segment of the labor market where immigrant and native workers can actually be regarded as competitors. In order to investigate the impact of immigration on employment opportunities, one therefore has to determine the relevant labor market segments. Analysis of aggregate production technologies suggests that different skill levels are not perfectly substitutable in an economy, but rather employed in certain proportions. If this is correct, an ideal strategy to estimate the labor market impact of immigration is to investigate changes in the relative remuneration of different skill groups in response to changes in the relative supply of these skills through immigration. The obvious problem with this approach is that if workers are classified according to standard measures of skills, such as the level of educational attainment, there will be too little identifying variation.

However, human capital theory in the tradition of Mincer (1974) and Becker (1975) stresses that skills acquired on-the-job are an important component of knowledge raising individual productivity. Empirical evidence furthermore suggests that similarly educated workers with different experience levels are not perfect substitutes. For example, the seminal study by Welch (1979) analyzing the impact of the baby boom on the wages of different birth cohorts shows that workers in more distant experience cells are less likely to influence each other's labor market outcomes than workers that are close in terms of number of years worked. Also the more recent evidence on the link between cohort size and wage structure in Card and Lemieux (2001) supports the hypothesis that different experience groups are less than perfect substitutes.

The insight that schooling and experience play a role in defining distinct skill groups may provide an better basis for an empirical analysis of how immigrants affect the em- 
ployment opportunities of natives. Provided that immigration into groups with a certain educational attainment is imbalanced across experience cells, there could exist a great deal more exogenous variation in supply shocks. This could help identifying the labor market impact of immigration. Of course, the key underlying assumption of this empirical approach is that there is a single national labor market for particular skill groups, so that one can only observe one wage-employment outcome for each group at a point in time.

Let $N_{i j t}$ be the number of native workers who have schooling level $i$, experience level $j$, who are observed at a point in time $t$. Likewise, let $M_{i j t}$ be the number of immigrants in the schooling-experience-time cell $(i, j, t)$. All workers observed with combination $(i, j)$ at a given point in time define a skill group. The immigrant supply shock for this skill group can then be measured by

$$
m_{i j t}=\frac{M_{i j t}}{N_{i j t}+M_{i j t}},
$$

i.e. the percentage of total labor supply in a skill group coming from immigrant workers. ${ }^{1}$ The most basic regression model to analyze the empirical correlation between an immigrant shock and labor market outcomes of natives pools the data for all skill-period observations to estimate:

$$
y_{i j t}=\beta m_{i j t}+\sigma_{i}+\nu_{j}+\theta_{t}+\varepsilon_{i j t}
$$

where $y_{i j t}$ is the mean value of a particular labor market outcome for natives in the $(i, j)$ cell at a point in time $t, \sigma_{i}$ is a vector of fixed effects associated with the level of schooling, $\nu_{j}$ is a vector of fixed effects associated with the level of experience, $\theta_{t}$ is a vector of period fixed effects, and $\varepsilon_{i j t}$ is a remainder error term. The hypothesis to be tested is if the estimate of the parameter $\beta$ is significantly different from zero and exhibits the expected negative sign.

The linear fixed effects in the basic empirical model (2) control for systematic differences in the labor market outcomes with regard to different educational attainment, experience, and periods. In the empirical analysis below, we will most of the time employ an extended specification, which controls for a full set of interactions between the vectors of fixed effects. To be specific, we will estimate the following regression model:

$$
y_{i j t}=\beta m_{i j t}+\sigma_{i}+\nu_{j}+\theta_{t}+\sigma_{i} \nu_{j}+\sigma_{i} \theta_{t}+\nu_{j} \theta_{t}+\varepsilon_{i j t} .
$$

\footnotetext{
${ }^{1}$ An alternative measure for the immigrant supply shock would be the percentage increase in the supply of the skill group that can be attributed to immigration, $m_{i j t}^{s}=M_{i j t} / N_{i j t}$. Estimation results obtained on this basis are not substantially different.
} 
This extension allows for the possibility that experience profiles are not the same across educational groups through the interaction $\sigma_{i} \nu_{j}$. Moreover, the interactions $\sigma_{i} \theta_{t}$ and $\nu_{j} \theta_{t}$ control for the possibility that the correlation between labor market outcomes and the level of schooling respectively experience is not constant over the observation period. Note that the inclusion of the interaction term $\sigma_{i} \nu_{j}$ implies that the impact of the immigrant supply shock on natives' labor market opportunities is identified through changes within education-experience cells over time.

\section{Data and Sample}

The empirical analysis is based on repeated cross sections drawn from the Regional File of the IAB Employment Subsample (IABS-R). The structure of the IABS-R is very similar to the more widely used standard IAB Employment Subsample, but covers a longer time span ranging from 1975 to $1997 .^{2}$ The IABS-R is based on a one percent random sample drawn from West German Social Security records, to which all employers are obliged to report at least once a year. The wage information available for employed individuals therefore covers all earnings subject to statutory Social Security contributions. Any individual who worked in a job covered by Social Security at least once during the observation period may be a member of the sample. For these individuals, the IABS-R not only records employment spells, but also periods of drawing benefits from unemployment insurance.

The IABS-R is generally representative for both the native and the foreign population in Germany. It is suitable for the purpose at hand because it records information on wages, employment status, age, completed education, and nationality. The data has some limitations, however. First, by construction it does not cover occupations that are exempted from statutory Social Security. This concerns workers employed in minor employment contracts (Geringfügige Beschäftigung) and especially the self-employed. ${ }^{3}$ If there was some differential sorting between immigrants and natives into these types of employment, this could be a source of bias in the empirical analysis.

Second, in contrast to the available information on labor market outcomes in the IABS-R, the data on educational attainment is not taken from the Social Security records

\footnotetext{
${ }^{2}$ For an introductory description of the IAB Employment Subsample, which for the most part also applies to the IABS-R, see Bender, Haas, and Klose (2000).

${ }^{3}$ A third exempted group of workers is civils servants, but in this case it seems very plausible to assume that due to legal restrictions, immigrants cannot substitute natives.
} 
but provided by employers. As a consequence, the level of schooling is missing for about 15 per cent of the sampled individuals and where it is available may be infected by misreporting. Again, this may bias the empirical estimates supposed that the probability of non-reporting or mismeasurement were correlated with immigrant status. Unfortunately, so far the nature of the reporting problems in the education variable of the IABS-R has not been researched, so that it is difficult to know if this is indeed a relevant problem in the present context.

Finally, the status as a an immigrant is only identified on the basis of non-German citizenship. The fact that the data lacks the date of entry into Germany has clear disadvantages. In particular, we cannot distinguish foreign citizens who are born abroad from those born in Germany. As a result, the immigrant supply shocks derived from the data will partly reflect the second generation of the population of foreign origin entering the labor market, rather than a fresh influx of international migrants. This would pose less of a problem, if it was possible to impute, in the tradition of Chiswick (1978), the effective labor market experience of foreigners by estimating the differential value that German employers attach to experience acquired abroad or at home. However, this type of analysis would again require information on immigrants' duration of stay in Germany.

In the regression analysis, the dependent variables will be the mean of log wages and the unemployment rate of the native population in a skill group. The IABS-R data comes in the form of an event history, which allows determining these two variables at any given point in time. We decide to represent labor market outcomes in a given year by the cross section as observed on the $1^{\text {st }}$ of September. Much of the empirical analysis will incorporate the complete set of available cross sections for the individual years $t=1975, \cdots, 1997$.

Wages are recorded in the data as gross earnings per day of an employment spell, which means that we can control for the length of the period worked, but not for exact working hours. As only categorized information on working hours (full-time, part-time, less than part-time) is available, we restrict the working sample to full-timers. Because earnings are subject to Social Security contributions only up to a unitary threshold, recorded wages are top-coded. To avoid bias from eliminating individuals whose wage is at or above the threshold, we have to impute censored wages. We therefore run, in a first step, a tobit regression including age, education, occupation, sector and job type variables. In a second step, wages are simulated taking random draws from the estimated conditional truncated 
distribution for censored individuals. Wage data are deflated to 1995 values by using the consumer price index.

Regarding employment outcomes, we define the relevant unemployment rates $\mu_{i j t}$ by the number of recipients of unemployment benefits with German nationality in a $(i, j, t)$ cell, $N_{i j t}^{u}$, relative to the entire native population that is observed in this skill group:

$$
\mu_{i j t}=\frac{N_{i j t}^{u}}{N_{i j t}}
$$

This measure obviously deviates from the official unemployment rate concept. First, the nominator ignores individuals who are not eligible for benefits and therefore not registered as unemployed. Second, the denominator only consists of the population as registered in the data - workers employed in a job covered by Social Security and benefit recipientsinstead of the total of dependent employees and registered unemployed. We also cannot observe if immigration into a labor market discourages native workers from searching, i.e. if immigration impacts on the rate of labor market participation. Overall, the unemployment rates retrieved from the IABS-R appear smaller than the official measures. A main reason for this, however, is undersampling of unemployment spells in the process of constructing the original data set. ${ }^{4}$ However, as this is process is random, there is no reason to speculate that it could lead to correlation between immigrant supply shocks and the unemployment rate measured for natives.

According to the concept explained in the previous section, classification of all individuals into skill group follows educational attainment and work experience. The data report four different types of formal qualification which refer to the highest degree qualifying for a job obtained by an individual. In particular, we distinguish between persons who did not finish an apprenticeship training, finished an apprenticeship training, graduated from a vocational school or college (Fachhochschule), or graduated from a university.

Classification of individuals according to experience is bound to be inaccurate. The data does not provide neither a direct measure of the total number of years worked, nor information on the actual age at entry into the labor market. Though the data in principle allows following individual labor market histories over time, calculating actual work experience on this basis would lead to many truncated or censored observations. It is therefore

\footnotetext{
${ }^{4}$ In the first years covered by the data set, this undersampling problem is so severe that it is not feasible to construct unemployment rates from the data. Hence the empirical analysis of unemployment outcomes will be limited to the period 1980-1997.
} 
necessary to approximate experience by individuals' current age and assuming a typical entry age entry associated with a particular occupational degree. Obviously, since many women at least temporarily withdraw from the labor market during periods of child rearing, this method will lead to reasonably accurate approximations only in the case of men. We hence eliminate women from the analysis.

For all men, we assume that the typical person without apprenticeship training accesses the labor market at the age of 16, the typical person with apprenticeship training at the age of 19, the typical (vocational) collage graduate at the age of 21 , and the typical university graduate at the age of $24 .^{5}$ As explained above, the data does not allow distinct approximations for natives and immigrants by differential weighting of years worked in the source country and in Germany. The analysis only looks at individuals with at most 35 years of labor market experience. For older men, the decision to withdraw from the labor market in order to retire early comes into play, and there is empirical evidence for systematic differences in early retirement behavior between Germans and immigrants (Bonin, Raffelhüschen, and Walliser 2000).

For much of the empirical analysis, skill groups are distinguished by classifying workers into experience intervals, namely 1-5 years of experience, 6-10, 11-15, 16-20, 21-25, 26-30, and 31-35. This means that with $i=1, \cdots, 4$ levels of occupational qualification, and $j=1, \cdots, 7$ levels of experience on the job, we obtain observations on immigrant supply shocks and natives' labor market outcomes in 28 skill groups, at a given point in time. By stacking the skill group data across the 23 available calendar years, we can exploit variation over 644 cells to estimate the empirical model (2), respectively (3). The immigrant supply shock for each skill cell is computed on the basis of 82,765 to 107,722 individual observations per year, of which between 8.9 and 11.2 percent represent immigrants.

\section{Empirical Evidence}

\subsection{Descriptive Statistics}

It is instructive to begin the empirical analysis by illustrating the immigrant labor supply shocks that may affect the labor market outcomes of natives. Figure 1 displays the percentage share of immigrants in the workforce as derived from our sample, i.e. the immigrant

\footnotetext{
${ }^{5}$ Experiments with alternative assumptions about the age at entry to the labor market did not lead to substantially different estimates.
} 
supply shock on the West German labor market as a whole. The quota of immigrants shows some remarkable variation over time, which is broadly consistent the the history of net immigration flows. In particular, the two phases of falling migrant labor supply in the mid 1970's and early 1980's overlap with a negative immigration balance corresponding to a recruitment ban. In the 1990's the immigrant share raises back to the initial level of around 11 percent, as Germany experienced a very substantial net influx of foreigners that reached more than 750,000 individuals in 1992. The reason why the immigrant quota does not increase substantially during the final years of the observation window is that during this period, a massive influx of East Germans and ethnic Germans from Eastern Europe, recorded as natives, enlarged the German workforce.

For the empirical analysis, it is important that there is sufficient dispersion in the immigrant supply shocks across skill groups. Figure 2 illustrates these supply shocks within experience categories, differentiated by our for different categories of occupational education, and their development over time. It is clear from this picture that there is a great of dispersion in immigrant supply shocks. First, these shocks vary substantially between categories of educational attainment. It if well known that in the past, immigration to Germany has greatly increased the supply of less-educated workers (up to 40 per cent), whereas the share of foreign workers in the upper education categories (normally less than 10 per cent) is much smaller.

What is equally important, the immigrant supply shocks within education categories do not equally affect all experience groups, and this imbalance changes over time. For example, immigrants raised the supply of workers without apprenticeship training and 15 to 20 years of labor market experience by around 40 percent in 1976, but only by less than a quarter in most other experience cells. In 1986, however, the highest immigrant share occurs in the cells of workers with 25 to 30 years of experience. A similar pattern is observed within the group of workers with apprenticeship training. Of course, these processes are a reflection certain immigrant cohorts moving through the age distribution. Therefore, in the empirical model (3), which identifies the labor market impact of immigration on the basis of changes occurring within education-experience cells over time, it will be necessary to employ clustered standard errors to adjust for serial correlation.

A comparison of the two upper and the two lower panels of Figure 2 shows that the immigrant supply shocks also are quite imbalanced over the different levels of education. 
In the tendency, the share of immigrant college and university graduates for the least experienced groups has declined over time, whereas for workers without an academic training, in part due to second-generation effects, the supply of immigrants with few years of experience, after a decline during the 1980s, again reaches or even exceeds the levels of the 1970s during the 1990s. As the older immigrants with an academic training climb up the age ladder, the overall share of the immigrant population at this education level exhibits a remarkable decline.

Turning to labor market outcomes, there are natural differences in wages experienced by the various education groups, and the relative outcomes furthermore change during the observation period. Table 1 summarizes the experience profiles of natives' log gross wages for the four different levels of educational attainment. There is a great deal of variation in the rate of wage growth by education and experience. Consider, for example, the samples of workers with apprenticeship training or the sample of university graduates. During the period 1976-1986, the wage at these education levels grew fastest for workers with 26-30 years of experience. In the decennium 1986-1996, however, wage growth was the steepest for the workers who were 1-5 years in the labor market.

It is worth noting that the changes of the experience-earnings profiles observed in the German data are different compared to the changes in returns to skills that have occurred since the 1980s in other countries, notably in the United States (Katz and Murphy 1992). For instance, it appears that the experience-earnings profile of workers without apprenticeship training grew relatively faster than that of workers with an academic education, and also became steeper. During the 1990s, workers with or without apprenticeship training at least could secure their wages in real terms, whereas real wages of vocational college or university graduates were declining.

In sum, the data show that immigration did not have a balanced impact on the supply of workers in segments of the labor markets defined by both education and experience. At the same time there appears to be a huge differences in labor market outcomes within education-experience-cells. Therefore, in principle there seems to be sufficient independent variation in the data to identify the labor market impact of immigration on natives. Before proceeding to a formal econometric analysis, it is instructive to look at scatter diagrams relating the changes in labor market outcomes for natives to the changes in immigrant labor supply within skill groups. Figures 3 and 4 show this relation for annual changes of wages 
and unemployment rates, respectively, after removing year fixed effects from the differenced data. The plots clearly illustrate that there is in fact substantial dispersion in both the independent and dependent variables of our empirical model, and that this dispersion is not merely driven by outliers associated with small sample sizes in certain education-experience cells. The raw data also illustrate, however, that there is no immediately obvious correlation between immigrant supply shocks and labor market outcomes, neither with regard to wages nor with regard to employment.

\subsection{Econometric Analysis}

We now turn to a formal analysis of the data. Table 2 presents the basic estimates of the adjustment coefficient $\beta$. Unless otherwise specified, the results are obtained from the regression model (3) including all the interactions between the education, experience and period fixed effects. Furthermore, regressions are weighted by the sample size used to construct the labor market outcome for native. Standard errors are clustered by education-experience cells to account for the possibility of serial correlation across skill group observations.

Consider initially the results obtained when the dependent variable is the log of gross wages of native men (see column 2 of Table 2). The estimate of the adjustment coefficient is -0.105 , and it is statistically significant at the one percent level. Note that since the regressor $m_{i j t}$ represents the population share of immigrants in a skill group, the estimated coefficient $\beta$ cannot immediately interpreted as an elasticity. To obtain an elasticity that represents the percent response in wages to a percent change in immigrant labor supply, define $m_{i j t}^{s}=M_{i j t} / N_{i j t}$, which can be interpreted as the percentage increase in the labor supply in cell $(i, j, t)$ stemming from immigration. On the basis of the approximation $\log m_{i j t}^{s} \approx 2\left(2 m_{i j t}-1\right),{ }^{6}$ the wage elasticity can be written as follows:

$$
\frac{\partial y_{i j t}}{\partial m_{i j t}^{s}}=\frac{1}{\left(1+m_{i j t}^{s}\right)^{2}} \times \beta,
$$

when $y_{i j t}$ represents the mean of the log wage in an education-experience cell at period t. Equation (5) shows that the proper wage elasticity is proportional to the estimated adjustment parameter $\beta$, weighted with a factor declining in the size of the immigrant supply shock. However, during the observation period migrant share in the male labor force is almost constant. If one evaluates the wage elasticity at the mean value of the

\footnotetext{
${ }^{6}$ See Borjas (2003) for a formal derivation.
} 
labor supply increase through immigration (-0.65 percent) the adjustment factor therefore is very close to one (0.987). Put differently, if one looks at the full sample, the proper wage elasticities at the mean in the German case will always be very close to the estimated adjustment parameter. For the most part then there is no need to report them.

From the basic model, we obtain a wage elasticity of -0.102. Put differently, a 10 percent increase in the share of foreigners relative to the native workforce in an educationexperience group reduces the wage of native men by about one percent. One may argue that this estimate represents a lower bound of the immigration effect. The immigrant share may be endogenous in the sense that the labor market attracts foreigners in those skill segments where wages are high. Even if this argument holds, it is remarkable that the estimated negative wage effect of immigrants penetrating a skill group in Germany appears to be much smaller than in the United States. At least, our estimate is much smaller than the estimates in the range of four percent Borjas (2003) obtained from the skill group approach on the basis of decennial U.S. Census data.

The regression results for the basic model also indicate (see row 3 of Table 2) that the immigrant supply shocks do not have a significant effect on the unemployment rate of native men. If anything, the conclusion to be drawn from this result is that the labor market adjustment appears to work through wages rather than employment.

The remaining rows of Table 2 perform various specification tests to check the robustness of the results. The coefficients reported in the second row indicate that the estimates do not substantially change if the regressions are not weighted by the size of the skill groups in our sample, though the estimated wage elasticity becomes somewhat larger. The results are basically identical to those obtained from the basic estimation when regression are weighted only with the number of employed individuals in a skill group.

Row 4 of the table addresses the problem that differences in the immigrant supply shock $m_{i j t}$, as defined by (1), over time may be either due to a positive change in the number of foreigners, or a negative change in the number of native workers occupying an education-experience cell, for example through cohort effects in educational attainment. The last row of Table 2 reports the results obtained from a regression adding the log of the native workforce in a skill group, $N_{i j t}$, as a regressor. It turns out that the estimated wage adjustment parameter gets statistically insignificant. The impact of the immigrant supply shock on native employment is positive and statistically significant, suggesting a 
complementarity between natives and foreigners even within skill groups. These results suggest that the adjustment parameters obtained from the basic regression model (3) need to be interpreted with some caution, as they may not only capture the impact of an increase in the size of the immigrant workforce. In any case, they draw an even more favorable picture of the impact of immigrants on the labor market outcomes for natives.

The results would be roughly similar, if the regressions were estimated on the basis of a finer classification of skill groups. Classifying workers by education into one-year experience cells, we obtain 3312 observations for the regression on wages, and 2592 observations for the regression on unemployment. In the basic model, the estimated adjustment coefficient for wages is -0.104 with a standard error of 0.013 , and the estimated adjustment coefficient for unemployment rates is 0.005 with a standard error of 0.009 . In the model adding $\log N_{i j t}$ as a regressor, the wage adjustment coefficient for wages remains statistically insignificant, whereas the employment adjustment coefficient (-0.042) gets closer to zero, but with a standard error of 0.015 it still is statistically significant.

The coefficients reported in Table 2 were obtained by pooling all skill groups across all years of the sample period. Table 3 reports the coefficient estimated for different periods, which reflect the different phases of immigrant supply shocks at the aggregate level apparent in Figure 1. The results illustrate that while in each period immigrant supply shocks are negatively correlated with earnings, the effect is only significant during the period 1985-89 when where was a slight immigrant outflow of 0.16 percent, in terms of the native workforce. Evaluated at the sample mean, the wage elasticity then is -0.237 , which is still at the lower end of the estimates by Borjas (2003).

The insignificant adjustment parameter on the native unemployment rate when estimating the model using data for the complete sample period (1980-97) reflects that the sign of the estimated correlations actually switches across time. It turns out that the massive influx of foreign immigrants following German reunification had indeed a significant negative impact on the employment outcomes of native men. Given the mean value of the labor supply increase through immigration during the period 1990-97 (2.14 percent), the semi-elasticity of the unemployment rate with regard to immigrant penetration into a skill group is 0.145 . This means a 10 percent immigrant supply shock from immigration would raise the unemployment rate in a skill group by about 1.5 percent. 
Taken together, the evidence in Table 3 does not suggest that the elasticities based on the skill group approach are particularly stable. This finding contrasts the results in Borjas (2003) which suggest the ability of this approach to generate parameter estimates that are reasonably similar, or at least are not affected by wild sign switches across adjoining periods. In fact, the instability of the adjustment estimates in the German context resembles the problem of the spatial correlation framework that seems unable to provide stable estimates for the effect of immigration on the incumbent population (Borjas, Freeman, and Katz 1997).

In order to determine whether the estimated weak elasticities reflect a mixture of complementarity and substitutability of immigrants and natives within skill groups, or whether the significant results are being driven by particular skill groups, we have also run the regressions on sub-samples classified by the level of educational attainment and years of experience, respectively. When running the regressions by education level we stack the data across low-education workers (with and without apprenticeship training) and high-education workers (vocational college or university graduates), in order to maintain reasonable sample sizes. Moreover, if we ran the regressions within individual education groups, we could not include experience-period interactions to control for secular changes of the experience-earnings profile. When running the regressions by experience levels, we augment sample sizes by using one-year rather then five-year experience cells. The results from these regressions are on display in Tables 4 and 5 .

Table 4 indicates that the impact of immigrant supply shocks on the wages in the low and high education groups is mostly insignificant. The estimated adjustment parameter for low-education workers at least exhibits a stable negative sign. The only significant parameter occurs for the period 1985-89. It drives the significant negative elasticity when the regression is performed on the complete sample (see Table 2). Again, there is no clearcut pattern of the correlation between immigrant supply shocks and unemployment rates, though the parameter estimate on the basis of the high-education sample is significant and exhibits the expected positive sign. Looking at the estimation results for the period 199097, it is clear, however, that the significant positive parameter estimated for the period post unification (see Table 3) is identified on the basis of variation across the skill groups with low education. Overall, these results may be taken as evidence that a change in labor 
supply associated with immigration, if it has had an adverse impact at all, has harmed the population at the lower end of the education scale.

When the basic regression model is analyzed within separate experience groups, the estimated adjustment coefficients display substantial heterogeneity and swings of sign. Most of the significant effects occur within the top and bottom end of the experience scale. In particular, there is a clear cut adverse effect of immigrants on employment opportunities of native workers with more than 25 years of labor market experience, i.e., older native workers. The finding that immigrants are good substitutes for native labor in this particular segment of the labor market also comes through in the regression on native wages where the estimated adjustment parameter is negative in three of the four sub-periods, and strongly significant.

The results obtained from regressions on the sample of workers with short labor market experience are less clear. This is perhaps not coincidental considering that immigrant supply shocks, as measured in our sample, do not distinguish between the influx of new immigrants and second generation foreigners entering the labor market. At least, the strong post unification flows seem to have had an adverse impact on employment opportunities of the local youth. The simultaneous significant wage increase is hard to reconcile with a simple supply and demand framework, however. Before unification, if one only looks at the impact of changes in the supply of immigrant labor on employment rates of natives, it appears that within skill groups, immigrants were complements rather than substitutes to natives.

As mentioned above, a clear weakness of our data is that we do not observe the period when immigrants enter Germany and therefore cannot estimate their effective experience level as valued by employers. Put differently, we may classify migrants into the wrong skill group if we only rely on age in determining years of experience. In order to address this problem, we opt for an alternative approach that measures skills based on the notion that the labor market ultimately rewards the value of human capital incorporated in natives and immigrants by wages. As a measure of effective skills, one may therefore use the position of workers in the wage distribution. If this notion is correct, immigrants and natives with the same level of educational attainment and the same level of remaining skills should fall into the same wage range. 
To implement this alternative concept of effective skills, we slice the wage distribution of native workers with the same level of educational attainment, at a given period, into 20 quantiles covering five percent of the wage distribution each. We then count how many immigrant workers with the same educational attainment fall into the same quantile. On this basis, we define the immigrant supply shock in analogy to equation (1). ${ }^{7}$ The second column of Table 6 reports the results from a regression model that is specified exactly as our basic model (3), apart from a vector of quantile fixed effects replacing the experience group fixed effects.

This very different methodological approach to define skill groups does not confirm the regression results discussed above. Stacking the data over the entire sample period, there is no significant effect of immigrant supply shocks on wage growth in specific segments of the native wage distribution. In the early periods, we even measure a strongly significant correlation between the supply of immigrant workers and natives' wages, indicating the complementarity of the two types of workers within the reclassified skill groups.

As an alternative measure of effective skills, we group workers according to the type of occupational status (blue-collar, qualified blue-collar, and white-collar workers) instead of years of experience. Though there are clear differences in wage levels and earnings profiles between these occupational groups, this classification clearly provides a less satisfactory measure of skills than the wage measure analyzed before. In particular, to a certain extent individuals may have a choice to relocate in response to an immigrant supply shock, which could generate a bias similar to that present in the spatial correlation approach. The segmentation of labor markets along occupational status at any rate does not lead to any systematic and significant correlation between the immigrant supply shocks in an occupational status-education cell and natives' wages. This is also true when the regressions are based on a sample excluding workers with short labor market experience, in order to minimize the chances that native workers change to different career tracks to avoid competition from immigrants.

Finally, as many studies estimating spatial correlations have documented that immigrants supply shocks, while not being harmful to natives, lower labor market opportunities

\footnotetext{
${ }^{7}$ In this part of the analysis, we can of course only use immigrants and natives with a registered wage, which means that we ignore the unemployed in measuring immigrant supply shocks. Obviously it is then impossible to run regressions on the native unemployment rate.
} 
of earlier immigrants, ${ }^{8}$ we study to the impact of immigrants on immigrants. Table 7 reports the adjustment elasticities obtained from calculating log real wages and unemployment rates in the immigrant sample. The coefficients are generally different from those reported above for native workers (compare Table 2). Moreover, the adjustment elasticities are completely insignificant indicating a weak degree of substitutability within the immigrant population.

This result should be approached with caution, however. First, if recent immigrants cluster in education-experience cells where the labor market opportunities of migrant workers are particularly favorable, this would lead to a spurious positive (negative) correlation between the immigrant supply shocks and the wages (unemployment rates) in a skill group. Another problem may be that the experience-earnings profiles for immigrants confound a cohort and an aging effect, which may not be appropriately controlled for by the fixed effect interactions - the wage differential between more or less experienced immigrants in a cross section could reflect both the effect of seniority pay for "older" immigrant cohorts and the possibility that "younger" immigrants who inherently arrived more recently are systematically less skilled.

\section{Conclusion}

In this paper, we have tried to analyze the impact of immigrant supply shocks on the labor market opportunities of native German workers. Our empirical strategy exploits the substantial variation in the share of foreigners in the workforce that can be observed across different skill groups, if they are defined both in terms of educational attainment and the level of labor market experience. This skill group approach, which has generated very consistent estimates of the labor market effects of immigration for the United States, appears to work substantially less well if it is taken to a new context. In particular, the estimates derived from a range of possible specifications and different subsamples altogether appear to be fairly unstable, notably across adjacent sample periods. It therefore appears that the skill group approach cannot generally remedy a weakness of the more conventional approach to identify immigration effects on the basis of spatial correlations, namely that the dimension and even the algebraic sign of the estimated correlations wildly vary.

In sum, the picture emerging from our empirical evidence, which is based on register data on wages and unemployment covering the period 1975-97, is that penetration of for-

\footnotetext{
${ }^{8}$ See Borjas (1987) and Altonji and Card (1991) for examples.
} 
eigners into education-experience cells did not have a substantial negative impact on the labor market opportunities on native men in Germany. The central estimated wage elasticity indicates that a ten percent rise in the share of immigrants in the workforce would reduce wages of natives by less than one percent. Even if this estimate would only represent a lower bound of the actual wage effects because of some uncontrolled self-selection of migrants into skill groups with particularly high wage growth, it is clear that the adverse wage effects of immigration are much smaller in the German labor market than in the U.S. labor market where the parallel estimate ranges around four percent.

The estimated negative wage effect mostly stems from adjustments taking place prior to German unification. Post unification when the German labor market was hit by a massive influx of immigrants, it appears that the labor market adjusted mainly at the employment margin. Our estimates for the period after 1990 indicate that a ten percent increase in immigrant labor supply would increase the unemployment rate of natives by 1.5 percentage points. However, the effects of immigrant shocks do not hit all segments of the labor market uniformly. We find at least some evidence that the adverse effects are stronger for less-qualified and older workers.

Of course, the conclusion that the labor market effects of immigration are altogether small does not mean that the labor demand curve in Germany would not be downward sloping. It rather indicates that foreigners and natives even with the same level of measured skills are working in different segments of the labor market and therefore complement each other.

\section{References}

Altonji, J. G., And D. CARD (1991): "The Effects of Immigration on the Labor Market Outcomes of Less-Skilled Natives," in Immigration, Trade, and the Labor Market, ed. by J. M. Abowd, and R. B. Freeman, pp. 201-234. University of Chicago Press, Chicago.

Becker, G. S. (1975): Human Capital. Columbia University Press, New York, 2nd edn.

Bender, S., A. HaAs, and C. Klose (2000): "The IAB Employment Subsample 19751995," Journal of Applied Social Science Studies, 120, 649-662. 
Bonin, H., B. Raffelhüschen, and J. Walliser (2000): "Can Immigration Alleviate the Demographic Burden?," Finanzarchiv, 57, 1-21.

BorJAs, G. J. (1987): "Immigrants, Minorities, and Labor Market Competition," Industrial and Labor Relations Review, 40, 463-489.

(1994): "The Economics of Immigration," Journal of Economic Literature, 32, $1167-1717$.

(2001): "Does Immigration Grease the Wheels of the Labor Market?," Brookings Papers in Economic Activity, pp. 69-119.

(2003): "The Labor Demand Curve is Downward Sloping: Reexamining the Impact of Immigration on the Labor Market," Quarterly Journal of Economics, 118, 1335-1374.

Borjas, G. J., R. B. Freeman, and L. F. Katz (1997): "On the Labor Market Impacts of Immigration and Trade," in Immigration and the Work Force: Economic Consequences for the United States and Source Areas, ed. by G. G. Borjas, and R. B. Freeman, pp. 213244. Chicago University Press, Chicago.

CARD, D. (1990): "The Impact of the Mariel Boatlift on the Miami Labor Market," Industrial and Labor Relations Review, 43, 245-257.

(2001): "Immigrant Inflows, Native Outflows, and the Local Labor Market Impacts of Higher Immigration," Journal of Labor Economics, pp. 22-64.

Card, D., and T. Lemieux (2001): "Can Falling Supply Explain the Rising Return to College for Younger Men? A Cohort-Based Analysis," Quarterly Journal of Economics, 116, 705-746.

Chiswick, B. R. (1978): "The Effect of Americanization on the Earnings of Foreign-Born Men," Journal of Political Economy, 86, 897-921.

Grossmann, J. B. (1982): "The Substitutability of Natives and Immigrans in Production," Review of Economics and Statistics, 54, 596-603.

Hamermesh, D. (1993): Labor Demand. Princeton University Press, Princeton.

Johnson, G. E. (1980): "The Labor Market Effects of Immigration," Industrial and Labor Relations Review, 33, 331-341.

Katz, L. F., and K. K. Murphy (1992): "Changes in the Wage Structure, 1963-87: Supply and Demand Factors," Quarterly Journal of Economics, 107, 35-78.

Lalonde, R. J., and R. H. Topel (1996): "Economic Ipact of International Migration and the Economic Performance of Immigrants," in Handbook of Population and Family Economics, ed. by M. R. Rosenzweig, and O. Stark, pp. XXX-XXX. North-Holland, Amsterdam.

Mincer, J. (1974): Schooling, Experience, and Earnings. Columbia University Press, New York.

Welch, F. (1979): "Effects of Cohort Size on Earnings: The Baby Boom Babies' Financial Bust," Journal of Political Economy, 87, S65-S97. 
Figure 1: Aggregate Immigrant Supply Shocks 1975-1997

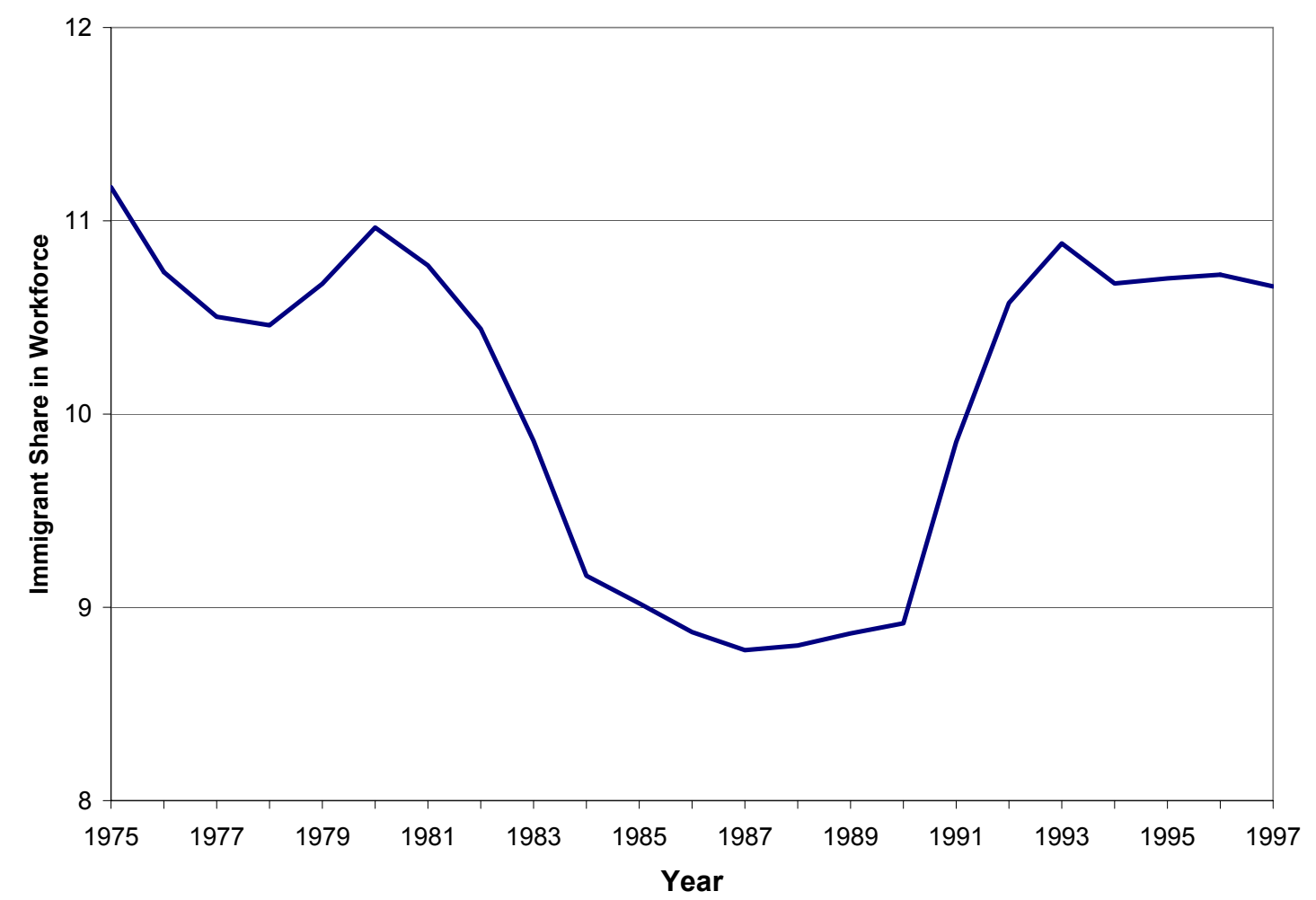

Notes: Immigrant supply shock is defined as the share of immigrants in the labor force relative to the total labor force. Source: Own calculation on the basis of the IABS-R. 
Figure 2: Immigrant Supply Shocks 1976-1996
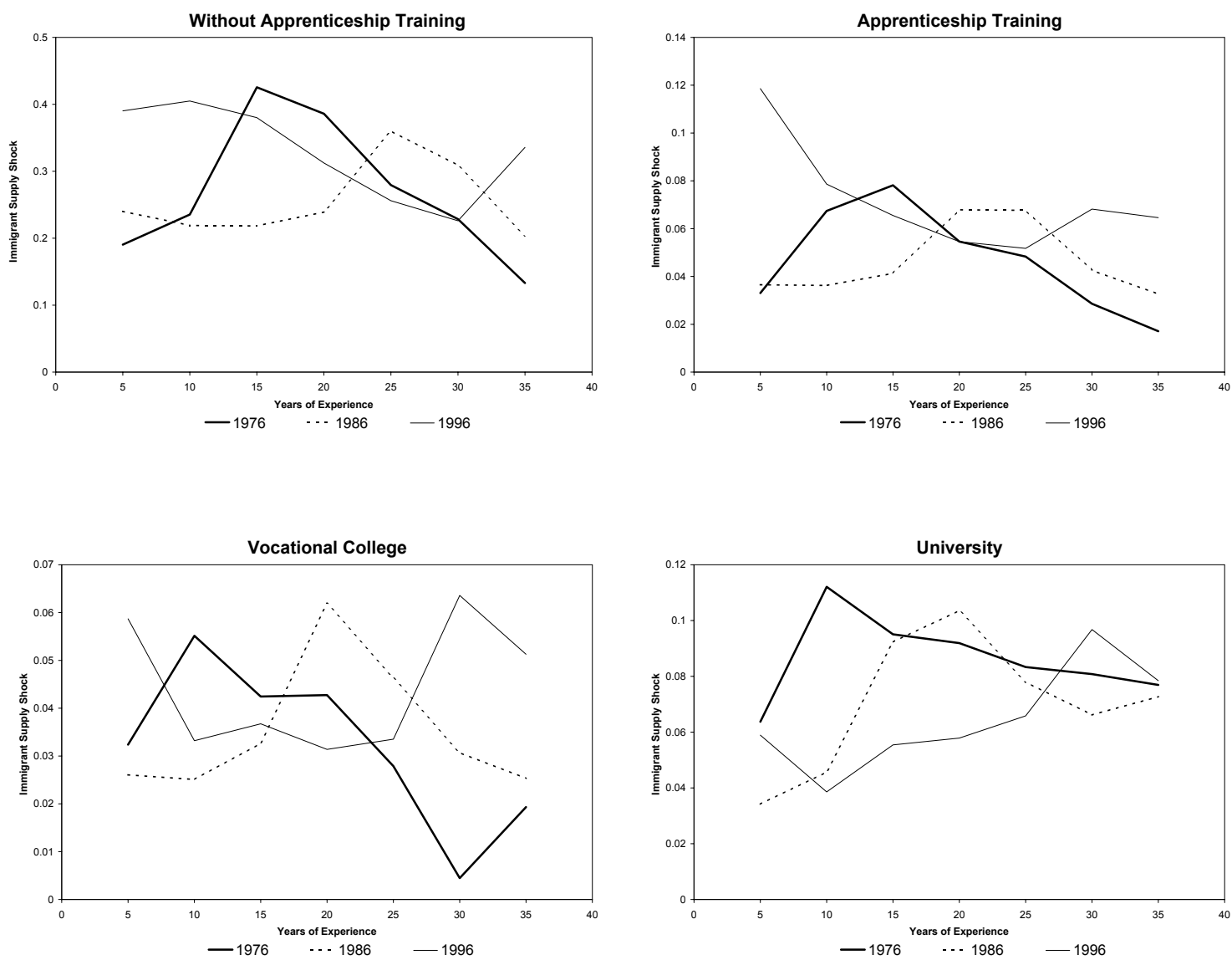

Notes: Immigrant supply shocks as defined by equation (1). Source: Own calculation on the basis of the IABS-R. 
Figure 3: Scatter Diagram Relating Wages and Immigration, 1975-97

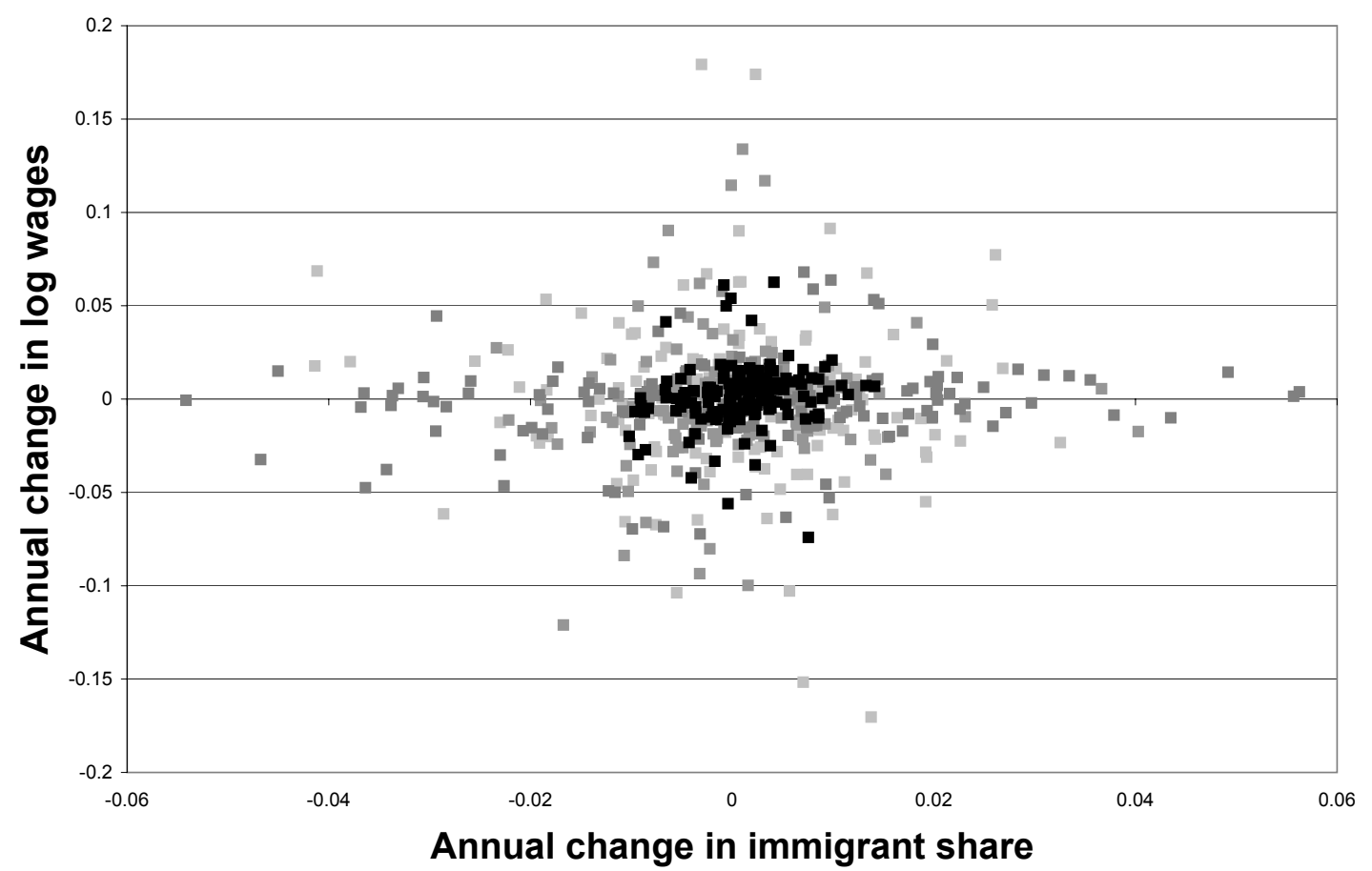

Notes: Each point in the scatter represent the yearly change in the mean of the log daily gross wage for a native education-experience group and the corresponding change in the immigrant supply shock. Year fixed effects have been removed from the data. The shading of an individual point in the scatter indicates the sample size of a skill group. The black dots represent the skill groups for whom the number of observations ranges in the top quartile, whereas the lightes grey dots represent the skill groups for whom the number of observations ranges in the bottom quartile. Source: Own calculation on the basis of the IABS-R. 
Figure 4: Scatter Diagram Relating Unemployment Rates and Immigration, 1980-97

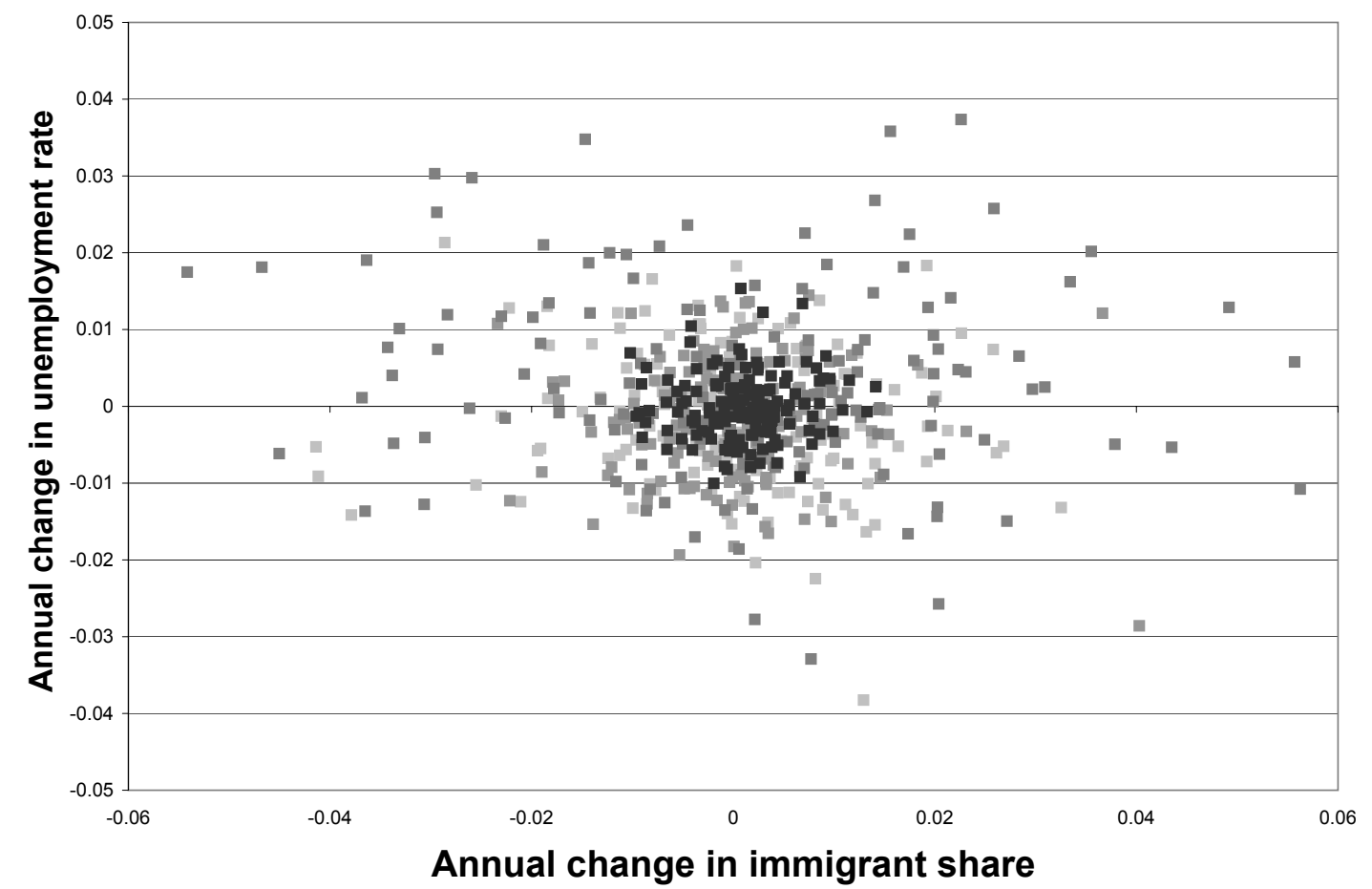

Notes: Each point in the scatter represent the yearly change in the mean of the unemployment rate for a native education-experience group and the corresponding change in the immigrant supply shock. Year fixed effects have been removed from the data. The shading of an individual point in the scatter indicates the sample size of a skill group. The black dots represent the skill groups for whom the number of observations ranges in the top quartile, whereas the lightes grey dots represent the skill groups for whom the number of observations ranges in the bottom quartile. Source: Own calculation on the basis of the IABS-R. 
Table 1: Log Real Wages of Native Male Workers 1976-96

\begin{tabular}{lcccccc}
\hline \hline \multirow{2}{*}{ Education } & Years of & \multicolumn{3}{c}{ Wage Levels } & \multicolumn{2}{c}{ Wage Changes } \\
& Experience & 1976 & 1986 & 1996 & $1976-86$ & $1986-96$ \\
\hline \hline No apprenticeship training & $1-5$ & 4.305 & 4.381 & 4.353 & 0.0758 & -0.0275 \\
& $6-10$ & 4.612 & 4.686 & 4.706 & 0.0746 & 0.0198 \\
& $11-15$ & 4.702 & 4.795 & 4.842 & 0.0934 & 0.0460 \\
& $16-20$ & 4.759 & 4.840 & 4.906 & 0.0809 & 0.0667 \\
& $21-25$ & 4.767 & 4.871 & 4.918 & 0.1039 & 0.0469 \\
& $26-30$ & 4.751 & 4.910 & 4.936 & 0.1587 & 0.0256 \\
With apprenticeship training & $31-35$ & 4.747 & 4.906 & 4.966 & 0.1589 & 0.0600 \\
& $1-5$ & 4.624 & 4.673 & 4.777 & 0.0489 & 0.1045 \\
& $6-10$ & 4.806 & 4.864 & 4.946 & 0.0583 & 0.0821 \\
& $11-15$ & 4.911 & 4.995 & 5.060 & 0.0834 & 0.0650 \\
& $16-20$ & 4.942 & 5.074 & 5.118 & 0.1321 & 0.0446 \\
& $21-25$ & 4.932 & 5.128 & 5.162 & 0.1961 & 0.0336 \\
& $26-30$ & 4.923 & 5.126 & 5.185 & 0.2029 & 0.0583 \\
& $31-35$ & 4.910 & 5.087 & 5.197 & 0.1763 & 0.1103 \\
& $1-5$ & 4.883 & 4.824 & 4.934 & -0.0581 & 0.1093 \\
University & $6-10$ & 5.098 & 5.141 & 5.187 & 0.0434 & 0.0456 \\
& $11-15$ & 5.280 & 5.333 & 5.348 & 0.0535 & 0.0154 \\
& $16-20$ & 5.366 & 5.445 & 5.393 & 0.0788 & -0.0517 \\
& $21-25$ & 5.444 & 5.540 & 5.431 & 0.0956 & -0.1092 \\
& $26-30$ & 5.374 & 5.552 & 5.456 & 0.1788 & -0.0959 \\
& $31-35$ & 5.348 & 5.551 & 5.479 & 0.2023 & -0.0714 \\
& $1-5$ & 4.980 & 5.046 & 5.095 & 0.0663 & 0.0484 \\
& $6-10$ & 5.300 & 5.298 & 5.311 & -0.0023 & 0.0128 \\
& $11-15$ & 5.476 & 5.488 & 5.423 & 0.0126 & -0.0647 \\
& $16-20$ & 5.548 & 5.579 & 5.469 & 0.0308 & -0.1103 \\
& $21-25$ & 5.484 & 5.633 & 5.495 & 0.1491 & -0.1378 \\
& $26-30$ & 5.512 & 5.705 & 5.485 & 0.1933 & -0.2201 \\
& $31-35$ & 5.501 & 5.671 & 5.500 & 0.1700 & -0.1702 \\
\hline \hline
\end{tabular}

Notes: The table reports the mean of the log daily wage in each education-experience cell. All wages are deflated to 1995 prices using the consumer price index series. 
Table 2: Impact of Immigrant Supply Shocks on Labor Market Outcomes of Native Men

\begin{tabular}{lcc}
\hline \hline \multirow{2}{*}{ Specification } & \multicolumn{2}{c}{ Dependent Variable } \\
\hline \hline 1. Basic estimates & Log Gross Daily Wages & Unemployment Rate \\
2. Unweighted regression & $-.105^{* *}$ & -.001 \\
& $(.036)$ & $(.025)$ \\
3. Employed workers as alternative weights & $-.135^{* *}$ & .018 \\
& $(.050)$ & $(.019)$ \\
4. Log native labor force as regressor & $-.107^{* *}$ & -.001 \\
& $(.041)$ & $(.025)$ \\
& -.033 & $-.073^{* *}$ \\
\hline
\end{tabular}

Notes: The table reports the coefficient of the immigrant supply shock from regressions where the dependent variable is the mean labor market outcome for a native skill group. Standard errors are reported in parentheses and have been adjusted for clustering within skill-experience-cells. ** indicates that the estimated parameter is significant a the five percent level. If not noted otherwise, regressions are weighted by size of the skill-experience-year cells and contain a full set of interactions between education, experience and education effects, as specified in equation (3). The regressions have 664 observations, and the regression on unemployment rates has 504 observations. 
Table 3: Basic Specification Estimates by Period

\begin{tabular}{ccc}
\hline \hline \multirow{2}{*}{ Period } & \multicolumn{2}{c}{ Dependent Variable } \\
\hline \hline $1975-1979$ & Log Gross Daily Wages & Unemployment Rate \\
& $(.155)$ & - \\
$1980-1984$ & -.077 & -.148 \\
& $(.084)$ & $(.100)$ \\
$1985-1989$ & $-.238^{* * *}$ & -.016 \\
& $(.052)$ & $(.057)$ \\
$1990-1997$ & -.084 & $.139^{* *}$ \\
& $(.091)$ & $(.061)$ \\
\hline \multirow{2}{*}{$1975-1997$} & $-.105^{* *}$ & -.001 \\
& $(.036)$ & $(.025)$ \\
\hline
\end{tabular}

Notes: The table reports the coefficient of the immigrant supply shock from regressions where the dependent variable is the mean labor market outcome for a native skill group. Standard errors are reported in parentheses and have been adjusted for clustering within skill-experience-cells. $* * *, * *$ indicates that the estimated parameter is significant a the one and five percent level, respectively. If not noted otherwise, regressions are weighted by size of the skill-experience-year cells and contain a full set of interactions between education, experience and education effects, as specified in equation (3). The regressions have 140 observations, apart from the regression on the period 1990-1997, which has 224 observations. 
Table 4: Basic Specification Estimates by Level of Education

\begin{tabular}{lcccc}
\hline \hline & \multicolumn{5}{c}{ Dependent Variable } \\
\multirow{2}{*}{ Period } & Low Education & High Education & Low Education & High Education \\
\hline \hline \multirow{2}{*}{$1975-1979$} & -.213 & -.681 & - & - \\
& $(.199)$ & $(.491)$ & & \\
$1980-1984$ & -.087 & -.165 & -.174 & $.296^{* *}$ \\
& $(.271)$ & $(.171)$ & $(.142)$ & $(.122)$ \\
$1985-1989$ & $-.249^{* * *}$ & .043 & -.021 & .063 \\
& $(.071)$ & $(.374)$ & $(.077)$ & $(.130)$ \\
$1990-1997$ & -.065 & .283 & .115 & -.163 \\
& $(.119)$ & $(.268)$ & $(.077)$ & $(.113)$ \\
& -.076 & .009 & -.012 & .033 \\
$1975-1997$ & $(.051)$ & $(.141)$ & $(.032)$ & $(.077)$ \\
\hline \hline
\end{tabular}

Notes: The table reports the coefficient of the immigrant supply shock from regressions where the dependent variable is the mean labor market outcome for a native skill group. Workers with and without apprenticeship training are classified as having low education, whereas vocational college and university graduates are classified as having high education. Standard errors are reported in parentheses and have been adjusted for clustering within skill-experience-cells. ${ }^{* * *},{ }^{* *}$ indicates that the estimated parameter is significant a the one and five percent level, respectively. If not noted otherwise, regressions are weighted by size of the skill-experience-year cells and contain a full set of interactions between education, experience and education effects, as specified in equation (3). The regressions have 140 observations, apart from the regression on the period 1990-1997, which has 224 observations. 
Table 5: Basic Specification Estimates by Level of Experience

\begin{tabular}{|c|c|c|c|c|c|c|}
\hline \multirow[b]{4}{*}{ Period } & \multicolumn{6}{|c|}{ Dependent Variable } \\
\hline & \multirow{2}{*}{\multicolumn{3}{|c|}{$\begin{array}{l}\text { Log Gross Daily Wages } \\
\text { Years of Experience }\end{array}$}} & \multirow{2}{*}{\multicolumn{3}{|c|}{$\begin{array}{l}\text { Unemployment Rate } \\
\text { Years of Experience }\end{array}$}} \\
\hline & & & & & & \\
\hline & $1-10$ & $11-25$ & $26-35$ & $1-10$ & $11-25$ & $26-35$ \\
\hline \multirow[t]{2}{*}{ 1975-1979 } & -.349 & $-.174^{* * *}$ & $-.471^{* * *}$ & - & - & - \\
\hline & $(.737)$ & $(.021)$ & $(.092)$ & & & \\
\hline \multirow[t]{2}{*}{$1980-1984$} & .150 & -.086 & $-1.131^{* * *}$ & $-.790 * * *$ & -.009 & $.598^{* *}$ \\
\hline & $(.152)$ & $(.059)$ & $(.279)$ & $(.040)$ & $(.091)$ & $(.205)$ \\
\hline \multirow[t]{2}{*}{ 1985-1989 } & -.102 & -.116 & .109 & $-.269^{* * *}$ & -.109 & -.045 \\
\hline & $(.228)$ & $(.084)$ & $(.157)$ & $(.040)$ & $(.055)$ & $(.056)$ \\
\hline \multirow[t]{2}{*}{ 1990-1997 } & $1.224^{* * *}$ & -.015 & $-.168 * * *$ & $.272^{* * *}$ & .125 & $.063^{* * *}$ \\
\hline & $(.215)$ & $(.152)$ & $(.029)$ & $(.035)$ & $(.085)$ & $(.011)$ \\
\hline \multirow[t]{2}{*}{$1975-1997$} & .165 & $-.104^{* * *}$ & $-.124^{* * *}$ & $-.170^{*}$ & -.047 & $.097^{* * *}$ \\
\hline & $(.206)$ & $(.024)$ & $(.017)$ & $(.072)$ & $(.031)$ & $(.015)$ \\
\hline
\end{tabular}

Notes: The table reports the coefficient of the immigrant supply shock from regressions where the dependent variable is the mean labor market outcome for a native skill group. Standard errors are reported in parentheses and have been adjusted for clustering within skill-experience-cells. ***, **, * indicates that the estimated parameter is significant a the one, five and ten percent level, respectively. If not noted otherwise, regressions are weighted by size of the skill-experience-year cells and contain a full set of interactions between education, experience and education effects, as specified in equation (3). All regressions in the top and bottom experience group have 200 observations, and the regression in the medium experience group have 300 observations, apart from the regressions on the period 1990-1997, which have 320 and 480 observations, respectively. 
Table 6: Impact of Immigrant Supply Shocks on log Real Wages of Native Men: Basic Specification Estimates on the Basis of Alternative Skill Measures

\begin{tabular}{cccc}
\hline \hline & & Skill Measure & \multicolumn{2}{c}{ Occupational Status } \\
& & \multicolumn{2}{c}{ Years of Experience } \\
\multirow{2}{*}{ Period } & Quantiles of Wage Distribution & $1-35$ & $11-35$ \\
\hline \hline $1975-1979$ & $.650^{* * *}$ & .109 & .345 \\
& $(.210)$ & $(.324)$ & $(.206)$ \\
$1980-1984$ & $.597^{* *}$ & .143 & .124 \\
& $(.295)$ & $(.549)$ & $(.571)$ \\
$1985-1989$ & -.176 & .358 & .275 \\
& $(.495)$ & $(.451)$ & $(.525)$ \\
$1990-1997$ & .158 & -.149 & -.141 \\
& $(.272)$ & $(.202)$ & $(.189)$ \\
\hline \multirow{2}{*}{$1975-1997$} & .284 & .201 & .032 \\
& $(.202)$ & $(.110)$ & $(.089)$ \\
\hline \hline
\end{tabular}

Notes: The table reports the coefficient of the immigrant supply shock from regressions where the dependent variable is the mean labor market outcome for a native skill group. For the results reported the first column, immigrants are classified into skill groups by separating the wage distribution of native workers into 5-percent quantiles. For the results reported in the second and third, workers are classified by their status as blue-collar workers, qualified blue-collar workers, and white-collar workers. Standard errors are reported in parentheses and have been adjusted for clustering within skill-experience-cells. ***, ** indicates that the estimated parameter is significant a the one and five percent level, respectively. If not noted otherwise, regressions are weighted by size of the skill-experience-year cells and contain a full set of interactions between education, experience and education effects, as specified in equation (3). In the first (second, third) row, the regressions have $700(105,75)$ observations, apart from the regressions on the period 1990-1997, which have $1120(168,120)$ observations. 
Table 7: Impact of Immigrant Supply Shocks on Labor Market Outcomes of Immigrants

\begin{tabular}{lcc}
\hline \hline Specification & \multicolumn{2}{c}{$\begin{array}{c}\text { Dependent Variable } \\
\text { Log Gross Daily Wages }\end{array}$} \\
\hline \hline 1. Basic estimates & .021 & -.016 \\
& $(.060)$ & $(.037)$ \\
2. Unweighted regression & .027 & .020 \\
& $(.097)$ & $(.049)$ \\
3. Employed workers as alternative weights & .026 & -.016 \\
& $(.061)$ & $(.038)$ \\
4. Log native labor force as regressor & .105 & -.067 \\
\hline \hline
\end{tabular}

Notes: The table reports the coefficient of the immigrant supply shock from regressions where the dependent variable is the mean labor market outcome for an immigrant skill group. Standard errors are reported in parentheses and have been adjusted for clustering within skill-experience-cells. If not noted otherwise, regressions are weighted by size of the skill-experience-year cells and contain a full set of interactions between education, experience and education effects, as specified in equation (3). The regressions have 664 observations, and the regression on unemployment rates has 504 observations. 